\title{
The Future Prospect for the Evolution of Islamic Banking in Turkey
}

\author{
GUN Lamiha \\ Turgut Özal University, Ankara, Turkey
}

\begin{abstract}
In Turkey, banks having "Islamic" features that are long neglected have experienced strong business growth since 2003 that is just after the date of a moderate Islamic party which emerged victorious in parliamentary elections. While Turkey has only four "Islamic" banks, they capture more than $4 \%$ market share. The purpose of this research is to analyze the mechanisms that have allowed such a growth between 2002 (just after the financial crisis in 2001) and 2009, by comparing the results of activities of these four Islamic banks and find out possible opportunities that might exist in this sector. The results indicate that these institutions have a respectively higher risk-taking and internationally more fair open policy than the banks known as “conventional”. While Bank Asya (the market leader of the participatory banks in Turkey) and Albaraka Turk capture the individual customers, the other two institutions that are TurkiyeFinans and Kuveyt Turk capture the commercial customers. In addition, the development of these institutions seems to be very difficult because of the lack of Turkish Sukuk in Turkish banking context having no adequate liquidity. Moreover, in its political context, leading actors in Turkish political and economic structure reject utterly the existence of Sharia Board. In fact, it is clear that the Turkish banking sector is an untapped potential market that could be easily converted into an opportunity by improving the regulatory framework and communication strategy for these institutions. Indeed, since the controversy still exists around the concept of secularism, which is an impediment to the development of these banks called "Islamic" in Turkey, there is a necessity for a communication strategy to break down prejudices and to become popular for Islamic finance sector, which is still known very poorly and superficially by general public in Turkey.
\end{abstract}

Keywords: Islamic banking, participation banks, Turkish Sukuk, Sharia Board, risk-taking

\section{Introduction}

Since the 1970s, banking activities having Islamic character has largely evolved into a distinctive segment (Hassan \& Lewis, 2007). There are now over 200 Islamic banks operating in over 70 countries. Furthermore, it is estimated that the size of worldwide Islamic banking is close to 820 billion dollars (US Dollar) in 2008 (Islamic Financial Services Board, 2010). Since 2002, the Islamic finance is one of the fastest growing segments of the global and particularly Turkish financial sector (Hasan \& Dridi, 2010).

The Turkish banking sector has undergone profound changes since the 1984 Banking Act. After the 2001 financial crisis, Turkey gets to know an economic and political stability for the first time, which creates an

GUN Lamiha, Ph.D., Assistant Professor, Economics Department, Turgut Özal University.

Correspondence concerning this article should be addressed to GUN Lamiha, Turgut Özal University, Economics Department, Ayvalı Mah. 158. Cad. No:7 Etlik/Ankara/06010. E-mail: lgun@turgutozal.edu.tr. 
environment suitable particularly for investors wishing to take advantage of this upswing undergone by the country. Following the 2001 financial crisis, the BDDK ${ }^{1}$ (Banking Regulation and Supervision Agency-an independent organization since 1999 is responsible for the supervision of banks, improving the effectiveness of banking regulations and establishing an independent decision making mechanism) launched a program for restructuring of banking sector, management and resolution of the banks taken over by the $\operatorname{SDIF}^{2}$, strengthening of private banks and improving the efficiency of Turkish banking sector (Ongena \& Şendeniz-Yüncü, 2011). Through these reforms the assets of the sector have made considerable progress and effectiveness of institutions has improved (Ongena \& Şendeniz-Yüncü, 2011). This favorable macroeconomic environment is considerably beneficial to the banking sector, which is developing significantly for the last 10 years. Indeed the Turkish banking sector occupies a crucial position in the entire financial system, with $77 \%$ of total financial system assets owned by the banking sector. Among the institutions making up the Turkish banking sphere, some banks such as participation banks have grown well above their opponents. In 2009, there were 49 banks in Turkey, including 30 commercial banks (16 domestic and 14 foreign), among them four participation banks operated under the principles of Islam. The development of Islamic finance in Turkey, like any other country, is not a new "phenomenon". Indeed modern Islamic finance has emerged in Egypt in the 1960s and Malaysia in 1975 (Hassoune, 2008b).

During this period, the rate of growth of Islamic finance has evolved considerably to reach a peak of 30\% basically depending on asset classes. In addition, when the authors look at the degree of progress of Islamic finance, it shows us that Turkey has a niche position as Egypt, the United Kingdom, or even the United States (HSBC, 2010). ${ }^{3}$

From the geographical perspective, the Middle East represents the largest market in terms of Islamic finance with a market of over 350 billion dollars. Turkey ranking as 15th world power in 2010, with a population of more than 76 million people composed of 99\% Muslim population, constitutes a dynamic market having certain opportunities. All these factors create a suitable ground for the development of Islamic finance in Turkey. Thus, there might be namely, religious, social and economic reasons for this development, as interacted principal reasons.

The purpose of this research is to analyze the mechanisms that allowed such growth between 2002 (just after the financial crisis of 2001) and 2009 by comparing these four Islamic banks and update the opportunities and deficiencies that might exist in this sector.

\section{Islamic Finance vs. Conventional Finance}

The main difference between Islamic banks and conventional banks is the prohibition of the interest. When the authors take the five fundamental principles of Islamic finance basically known as not to get "riba" (interest/usury), prohibition of "gharar" or "maysir" (uncertainty or speculation) and "haram" (illicit sectors) have combined an obligation to share profits and losses and to have a tangible asset backing financial transactions, they find that these principles conform to Sharia ${ }^{4}$ law coincided with some part of the Muslim population, who wish to conduct their financial transactions in respect of Sharia. Therefore, there is a real

\footnotetext{
${ }^{1}$ BDDK: Bankacıllk Düzenleme ve Denetleme Kurumu (BRSA: Banking Regulation and Supervision Agency).

2 SDIF: Saving Deposit Insurance Fund (TMSF: Tasarruf Mevduatı Sigorta Fonu).

3 HSBC Amanah represents the largest Islamic financial services team of any international bank.

${ }^{4}$ Shari'ah [Shariah, Sharia, Shari’a, Sharia'a, Syariah]—sacred law revealed by God Almighty. Source: Glossory of Islamic Finance terms and contracts. Retrieved from http://www.cimaglobal.com/if.
} 
demand from customers and this segment of the population find a body that meets their needs and expectations through the participation banks.

As emphasized by Mohammed Nejatullah Siddiqi (as cited in Visser, 2010),

Islamic finance is not about developing a system which is very different to, or in conflict with, Western models, but rather about offering the choice of a system which is morally and ethically based, and therefore potentially appealing to everyone, Muslims and non-Muslims. (pp. 20-25)

However, the customer portfolio of these Turkish participation banks is not only composed of Muslims concerned about Sharia law, but also the clients regarded these banks as safer. Indeed, facing a financial crisis of 2001, the subprime crisis of 2007 and the following global economic crisis, the participation banks seem to be doing well by setting forth a more secure image. The Islamic banks are therefore considered "as a relatively safe haven against turmoil in global financial markets, and they embody a spirit of fairness and justice relative to the universe often unforgiving Western finance” (Hennie \& Zamir, 2008).

Hasan and Dridi (2010) conducted a study on the effects of global crisis on the Islamic and conventional banks by asking whether Islamic banks were more resistant than conventional banks in facing with a crisis. The variables used to measure the impact of the crisis on these two segments are the profitability, the banking loans, the banking assets, and external bank ratings. Their study shows that, in terms of the profitability, Islamic institutions are more resilient, low indebtedness of these institutions combined with their strong solvency has allowed them to keep a high demand and continued to increase bank lending, while maintaining the stability of their external ratings. The Islamic banks have therefore shown a certain "stability and strong resistance" compared with conventional banks (Moody's Investors Services, 2008). As can be seen in Table 1, credit rating granted by Moody's for these facilities is relatively well. According Bouslama (2008), this resistance is due to the low exposure of Islamic banks caused by toxic loans.

In addition some high-risk transactions are prohibited as short selling combines a mechanism for venture capital as the moudaraba ${ }^{5}$ (waiver of processing fee by the bank for losses posted by the company) supports the idea of justice and equity sought by customers.

Table 1

Credit Rating: Ba2 by Moody's (2010)

\begin{tabular}{|l|l|l|l|l|}
\hline & Bank Asya & AlBarakaTürk & KuveytTürk & TürkiyeFinans \\
\hline Rating & B/STABLE/B & BB-/STABLE/B & BB/STABLE/B & N/A \\
\hline
\end{tabular}

Islamic finance, in this vein, has a more ethical side. However, the "ethical finance" is not a new phenomenon since the father of modern capitalism, Adam Smith (Professor of Moral Philosophy) emphasized and advocated the ethical aspect of the economy (Subbarao, 2009). However, as pointed out by Dabadie (2010), Islamic finance is also exposed to risks that are often underestimated. Paradoxically, while the principles of

\footnotetext{
5 A Mudarabah contract is a profit sharing contract. Under a Mudarabah contract, the capital provider agrees to share the profits between themselves and the entrepreneur at an agreed ratio or percentage: (1) As a source of capital for a business venture, a businessman might consider undertaking a commercial project financed by funds from a bank under a Mudarabah contract. If agreeable, the bank supplies the finance to the businessman on the understanding that both parties will share the profits of the venture; and (2) As a deposit taking activity, money deposited in a bank by an individual or institution under a Mudarabah contract is treated as an investment in the bank by the individual or institution. The bank will use this investment to make profits from its trading activities, i.e., financing of individuals and businessmen. Under the Mudarabah contract, the bank will have agreed to give the depositor a share of its profits in return for the investment, based on a pre-agreed ratio. Source: Glossary of Islamic Finance terms and contracts. Retrieved from http://www.cimaglobal.com/if.
} 
justice and fairness are most important for Islamic finance, there is a certain lack of transparency on the exact nature of the risks encountered. Other risks appear as operational risks (El Qorchi, 2005) resulting from the lack of qualified personnel or even the risk of losing their assets due to their nature that is more or less associative. For some authors, Islamic finance does not have audit and risk management as a major concern (Gueranger, 2009), it would show a risk of default than to that of traditional finance (Cihak \& Hesse, 2008).

On the other hand, conventional banks are facing the same risk of asymmetric information ${ }^{6}$ (Hasan \& Dridi, 2010) as Islamic banks since the banking agent in need of funding has always more information than the lending agent having the capacity of funding and this would cause moral hazard and adverse selection problems. It is considered risky or not, it appears clearly that the religious orientation of a bank may be a defining characteristic in choosing a bank for the enterprise.

\section{Islamic Finance in Turkey}

Despite of this, when the authors look at the evolution of Islamic finance in Turkey, they see that after the 2001 financial crisis is coming into power of the moderate Islamist party AKP (Justice and Development Party) that the participation banks have become more popular than before. While Islamic finance is not new in Turkey (a special bank named DESIYAB (DevletSanayiveİşçiYatırımBankasıAşs/State Industrial and Workers' Investment Bank) opened the doors in 1975, followed by the creation of "Al Baraka Turk ve Finans" in 1985, and "Kuveyt Türk" appeared in 1989), this alternative finance stands as marginal and little-known. With the new banking regulations in 1999, economic stability and the victory of the moderate Islamist party (on November 3, 2002); Islamic finance enjoyed a new breath of fresh air. Certainly, the ruling party has not encouraged people to conduct to these institutions, but its moderate Islamic identity has given weight to this religious and social criteria. In other words, the ruling party has indirectly and unintentionally paved the way for these institutions. According to a study, these are generally young enterprises (small and medium), more transparent multi-banks focused primarily on industry and manufacturing moving towards the Islamic banks (Ongena \& Şendeniz-Yüncü, 2011).

As can be seen in the following figure (Figure 1), the four participation institutions in Turkey represent 21.4 billion of assets and constitute $4.12 \%$ of market share.

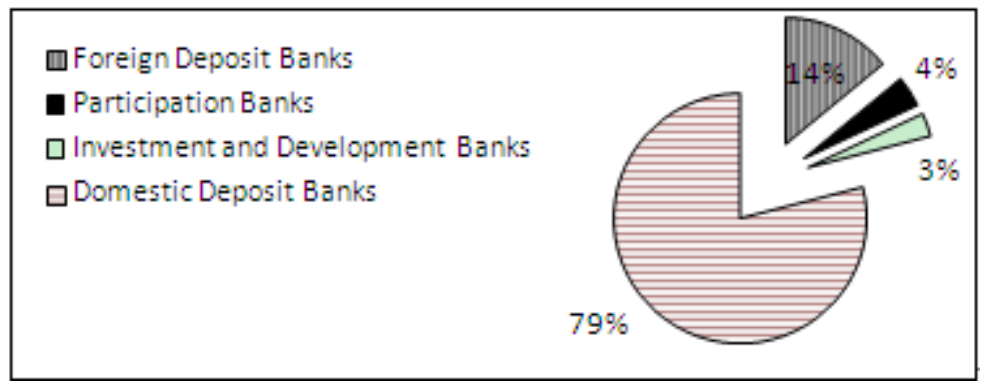

Figure 1. Market Share of Islamic Finance in Turkey (2009). Source: Table arranged according to the data stated by BDDK.

An in-depth analysis of these institutions shows that the Bank Asya is the leader in terms of assets, loans,

\footnotetext{
${ }^{6}$ Asymmetric information occurs when buyers or sellers are not equally informed about the quality of what they are buying and selling. The asymmetry always runs in the same direction, with the security issuer (borrower or party receiving financing) having more information than the investor (lender or party providing financing) about the issuer's (borrower or receiver of financing) future performance.
} 
and deposits and is located at the 17th position in the domestic market followed the loan market of Islamic finance by Türkiye Finans Bank. The latter created in 2005 is undoubtedly the fastest developing among the participation banks. Al Baraka Turk Bank, for its part, represents the least important market share of the sector despite of the fact that it is the oldest functioning Islamic bank in the market. On the other hand, after a difficult start, the market share of Turkish participation banks quadrupled in 10 years from $1.2 \%$ in 2001 to $4.8 \%$ in 2009. This growth is particularly visible when comparing the growth segment of Turkish banking system. The following figure (Figure 2) shows that the growth is relatively stronger regarding of loans, deposits and assets of Islamic banks comparing with the conventional banking sector.

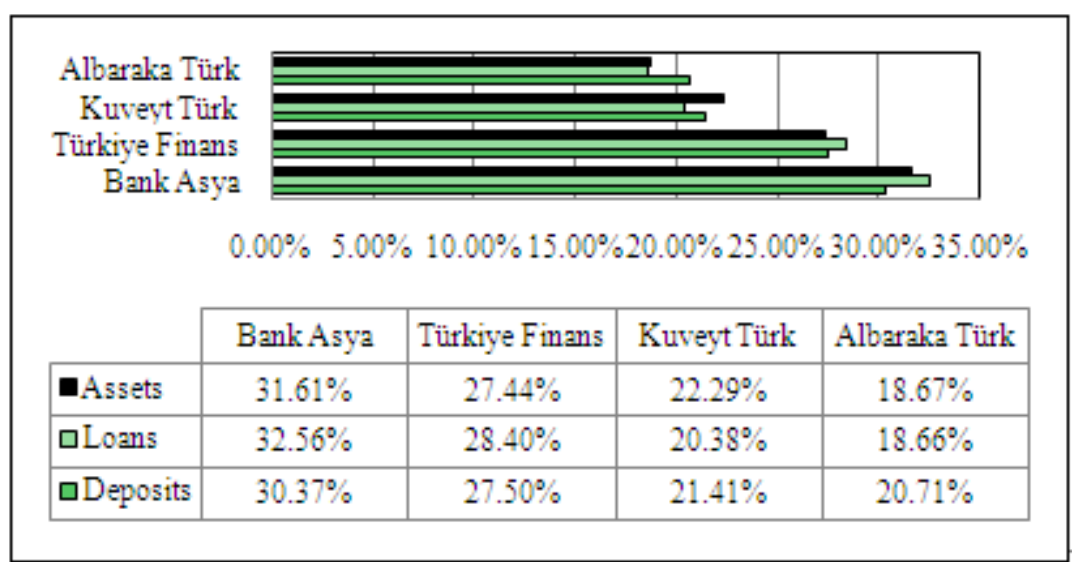

Figure 2. Market Share of Four Islamic Institutions (Turkey, 2009). Source: Table arranged according to the data stated by BDDK.

Growth is even more visible when the authors look at the number of newly opened bank accounts in these establishments, on average each year, increased by $18 \%$. The same scenario is valid for the rate of credit granted by the participation banks that reached record levels in 2006 with an increase of $133 \%$. As can be seen in Figure 3 this increase is also viable at the international level, since the rate of growth of Islamic assets in Turkey is much higher than those in other countries.

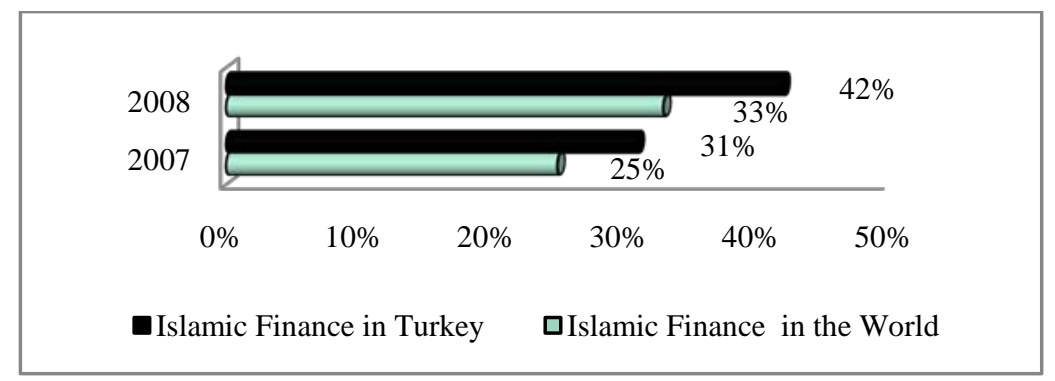

Figure 3. Growth of Islamic Banking Assets. Source: Table arranged according to the data stated by BDDK.

\section{Albaraka Turk, Bank Asya, Kuveyt Türk and Türkiye Finans}

It can be seen through the analysis of the profile of counterparties of such Islamic institutions that the Bank Asya and AlbarakaTürk are focused on an individual customer, while the other two institutions TürkiyeFinans and KuveytTürk are more focused on commercial customers. Indeed, the authors see that the Bank Asya provides $91 \%$ of its loans, while $81 \%$ of loans of Albaraka Turk Bank are given to the individual customers. While TürkiyeFinans and KuveytTürk grant respectively $88.5 \%$ and $74.5 \%$ of their credits for 
professionals. When focusing more closely on the profile of the loans granted to individuals, as can be seen in Figure 4 the authors see that AlbarakaTürk is the leader in mortgage credits (with 95\% of these loans granted to real estate loans) against 39\% of Bank Asya, which is the locomotive of the participation banks in the consumer loans that the roles are reversed in.

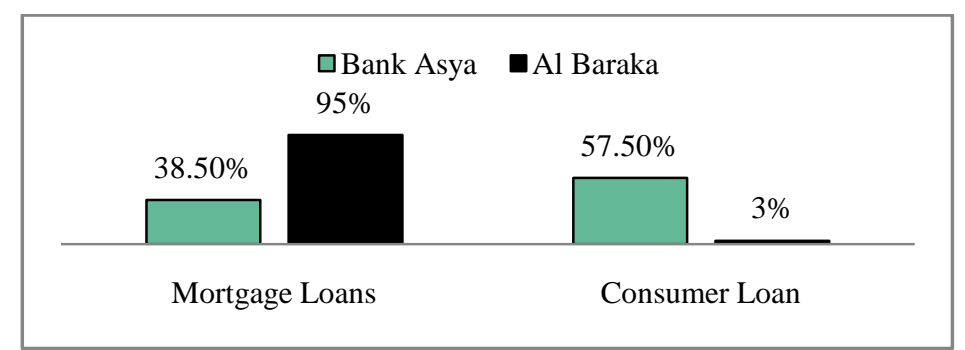

Figure 4. Profile of Loans Granted to Individual Customers by Bank Asya and Al Baraka (2008). Source: Table arranged according to the data stated by BDDK.

Further analysis of corporate credit of participation banks counterparties shows that the KuveytTürk Bank is the one that is most parallel to the Turkish GDP. Meanwhile, the AlbarakaTürk is the bank that has the most homogeneous distribution. The study of the financial profitability of these institutions shows that the Bank Asya is the most profitable of the participation banks (see Figure 5). However, as can be seen in Figure 6, analysis of risk-taking and managing risk exposure reveals that the Bank Asya has the riskiest position and the Capital Adequacy Ratio (CAR) ${ }^{7}$ of this bank is the lowest one. On the other hand, KuveytTürk stands as an establishment that is the most cautious (strong risk aversion) with a respectively higher CAR.

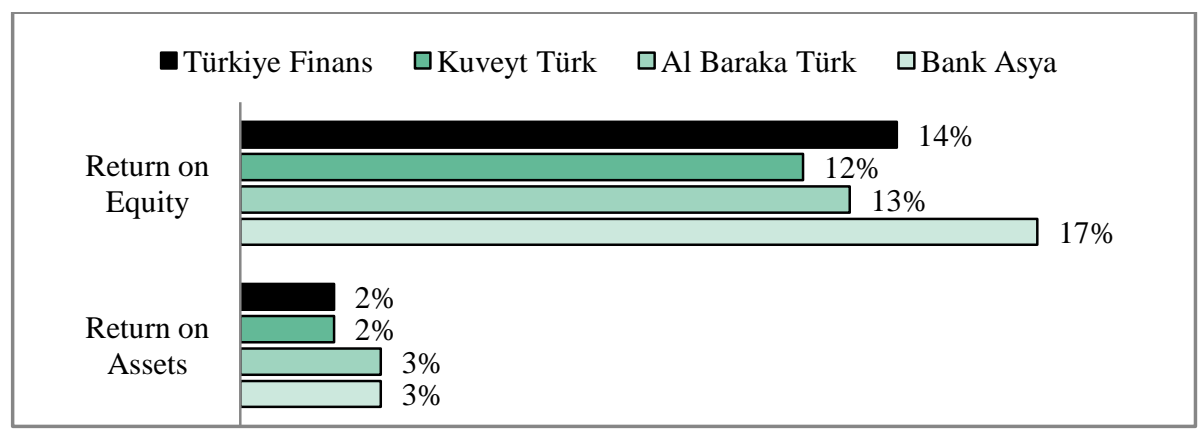

Figure 5. Financial Profitability of the Institutions. Source: Table arranged according to the data stated by BDDK.

However, our data (see Figure 7) indicate that risk taking by the participation banks is in general much more important than that realized by the traditional banking sector. This result could lead to a questioning of the idea that the market of Islamic finance is safer and less risky than classical financial institutions. In fact, according to some authors, the Islamic finance is exposed to the specific risks, alongside the ordinary banking risks at various degrees (Tariqullah \& Habib, 2001). Although the study of Hasan and Dridi (2010) showed that the low debt and high solvency of the participating banks allowed them to better withstand a crisis, it was questionable if in time and with the development of Islamic finance, participation banks would not be tempted to debt height of the conventional colleagues. In other words, if Islamic banking was as developed as conventional finance, could it withstand the crisis?

\footnotetext{
${ }^{7}$ Capital Adequacy Ratio (CAR) is a measure of the amount of a bank's core capital expressed as a percentage of its assets weighted credit exposures.
} 
In addition, it is difficult to make an accurate and comprehensive analysis of the composition of the shareholding of these Islamic institutions due to the lack of data. Indeed, apart from the $14.5 \%$ Turkish shareholder identified for the Bank Asya, the remaining $85 \%$ of the composition of the shareholding is unspecified.

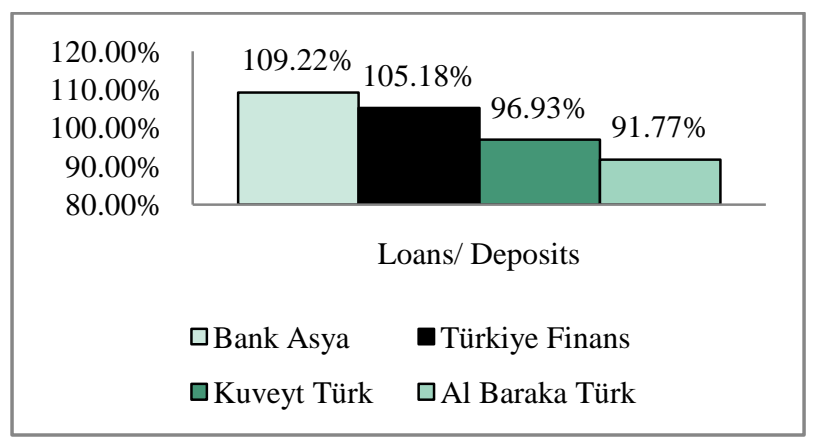

Figure 6. Risk-Taking. Source: Table arranged according to the data stated by BDDK.

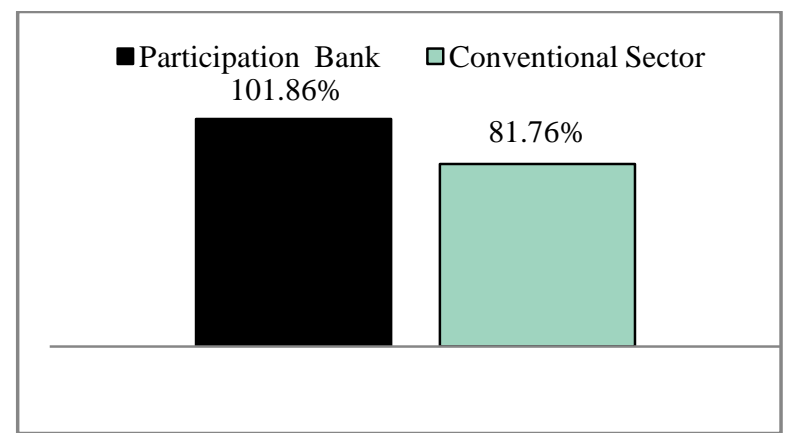

Figure 7. Risk-Taking by Islamic Sector vs. Conventional Sector (Turkey, 2010). Source: Table arranged according to the data stated by BDDK.

As it is show in the Figure 8, it is estimated through the data provided by the BDDK that the Albaraka Türk is composed of $83.9 \%$ foreign shareholder against $13 \%$ domestic shareholder, followed closely by that KuveytTürk is made up $70.2 \%$ of foreign shareholders and $19 \%$ Turkish shareholder. And finally $65 \%$ of the shares of TürkiyeFinans are held by foreigners, contrary to 35\% held by Turkish shareholders.

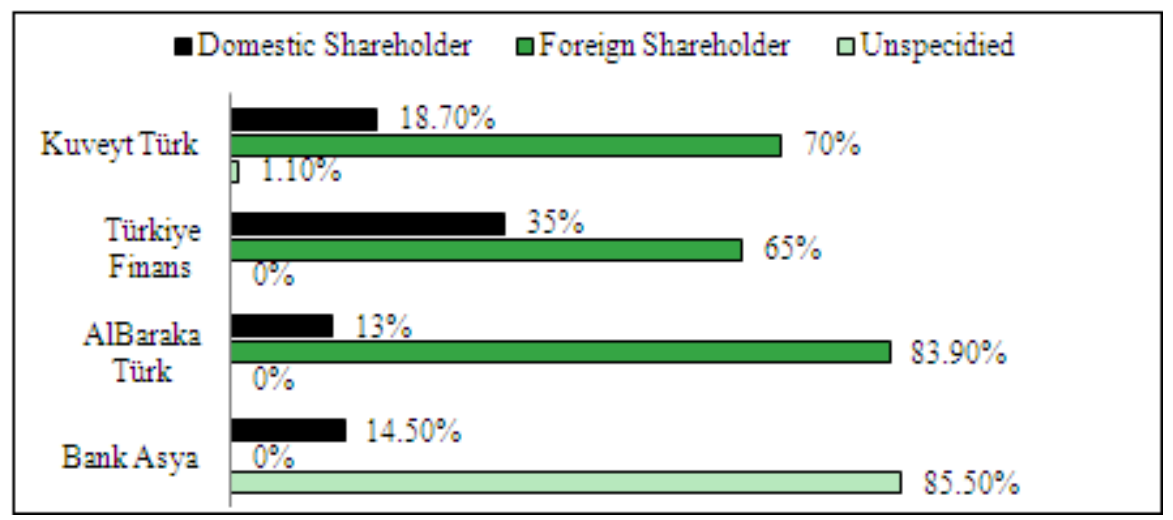

Figure 8. Composition of the Shareholding. Source: Table arranged according to the data stated by BDDK.

On the other hand, the study from the foreign currency deposits shows that confidence, in its general terms, on these establishments and on the Turkish economy is installed gradually step by step. In fact, as can be seen in 
Table 2, the shares of foreign currency deposits in these four institutions were superior to that held in local currency (Turkish lira) until 2005. It lasts until 2007 and the rate had decreased and finally below 50\% of the limit by re-election of moderate Islamist party AKP (as a sign of a long-awaited political stability and hoping to local and foreign investors), but remaining still average around 36\%. The AKP's re-election on June 12 will show us whether there really is a close link between political stability and share of foreign currency deposits in Turkey.

Table 2

Share of Foreign Deposits

\begin{tabular}{llll}
\hline Bank Asya & TürkiyeFinans & KuveytTürk & AlBarakaTürk \\
\hline $29 \%$ & $39 \%$ & $48 \%$ & $29 \%$ \\
\hline
\end{tabular}

Note. Source: Table arranged according to the data stated by BDDK.

\section{Reasons of Underdevelopment of These Four Institutions}

It is clear that compared with the dynamic development of the country's banks the Islamic finance institutions still have not reach the expected level. This underdevelopment can be explained through four factors.

First of all, an unstable political environment until 2002 and existing controversy, even today, around the concept of secularism fed by the prejudices in Islamic finance prevent these institutions to develop. On the other hand, the non-recognition of Sharia Board by the politicians remains an unresolved issue. In fact, each participation bank in Islamic finance has an internal board called as Council of Sharia (Sharia Board), which assembles and discusses before funding for each project by validating the Islamic nature of the transaction or the product submitted. Recognizing such a council would call into question the role of the BDDK, which is the ultimate authority, today, in Turkey to assess independently the banks.

As some authors pointed out, the current understanding of a Sharia Board is defined by the Accounting and Auditing Organisation of Islamic Financial Institutions (AAOIFI) ${ }^{8}$ in Bahrain. This body is built to standardise key practices of the industry. Their (Ahmed, 2002) definition is as follows:

A Sharia supervisory board is an independent body of specialised jurists in fiqh al-muamalat (Islamic commercial jurisprudence). However the Sharia supervisory board may include a member other than those specialised in fiqh al-muamalat but who should be an expert in the field of Islamic financial institutions and with knowledge of fiqh al-muamalat. The Sharia supervisory board is entrusted with the duty of directing, reviewing and supervising the activities of the Islamic financial institution to ensure that they are in compliance with Islamic Sharia rules and principles. The fatwas and rulings of the Board shall be binding on the Islamic financial institution. (p. 76)

Moreover, there also exists a religious risk that is to say: "the risk of disqualification of concurrent transactions, which is accepted as a priori Islamic, by another religious authority" (Dabadie, 2010). The absence of universal religious norms may create differences of opinion among Islamic banks, resulting in a need to harmonize the legal framework of these institutions.

The second factor is basically economic. In fact, Turkey, as an unstable country economically and politically, had a high rate of inflation with multi-digits. In this inflationary environment combined with an explosive public debt, the banking sector in general and Turkish participation banks in specific have not been

\footnotetext{
8 Accounting and Auditing Organisation for Islamic Financial Institutions (AAOIFI) — set up in 1991 to develop new standards and encourage the application of these standards, AAOIFI is now recognised as the main standard-setting organisation within Islamic finance. Since inception they have issued up to 70 standards on accounting, auditing, and governance, in addition to codes of ethics and Shari'ah standards. Source: Glossary of Islamic Finance terms and contracts. Retrieved from http://www.cimaglobal.com/if.
} 
able to develop.

The third factor is the slow evolution of the regulatory framework. Indeed, it is only with the Law Number 5411 dated January 1, 2006 that the special finance companies called as "Participation Banks" have legally taken place in the Turkish banking regulations.

Finally, the last factor is the structure of Turkish participation banks. Especially today, there is still the lack of Turkish Sukuk ${ }^{9}$ (investment certificates, which is for the bank to buy property and resell it immediately at a premium to another customer, who then pays back according to a timetable on which both parties agreed. It is like the equivalent of a bond fund in the West, in Islamic finance), which is probably the polar of Islamic finance.

\section{Conclusion}

In conclusion, the author can say that Islamic banks are operates themselves properly on their own because of the influence of the intangible environment. Inspired by the Shariah to establish their operational principles, Islamic banks differ from conventional banks in several respects. The relationship between Islamic banks and their customers is not a conventional relationship between the creditor and the debtor. It is a relationship where both parties share risks and profits. Another difference lies in the fact that profit is not the only goal of the Islamic bank. It must meet the religious rules and ethical needs. It must ensure that funds are invested according to Sharia. This "ethical" feature combined with effective demand and the strong performance of participating banks during the financial crisis of 2007 explains the development of Islamic finance in Turkey, as well.

Although risk-taking by participatory banks is significant for their strong solvency, the concept of risk sharing provides "a priori” feeling that Islamic banking is safer than conventional finance. Yet Islamic finance has not seen the expected development in Turkey. Indeed the absence of clear legal framework and universal religious norms raises doubts among customers who are becoming more reluctant to invest in these facilities combined have a stable economic course, but still fragile partly explain the slow evolution. The slow evolution of the regulatory framework for Turkish participatory banks and especially the absence of Turkish Sukuk are real obstacles to its development. Besides all the prejudice still existing today on Islamic finance shows a lack of marketing strategy from the four Islamic institutions present in Turkey. Without an effort to communicate, it is difficult to penetrate and take root in the financial market of Turkey for the participatory banks. Technical adjustments, legal, and regulatory framework are to provide for Islamic finance would actually financial alternative for the country.

\section{Discussion}

Alongside with the mentioned actions, it seems clear that a communication effort should be made by these four institutions to attract new depositors. Besides, a stronger banking system combined with a more stable macroeconomic environment and increasing investment made by the GCC $^{10}$ (Gulf Cooperation Council) show

\footnotetext{
9 Sukuk-Certificates of investment. Source: Glossary of Islamic Finance terms and contracts. Retrieved from www.cimaglobal.com/if.

10 The Gulf Cooperation Council (GCC) was established in an agreement concluded on May 25, 1981 in Riyadh, Saudi Arabia between Bahrain, Kuwait, Oman, Qatar, Saudi Arabia, and UAE. These countries declared that the GCC is established in view of the special relations between them, their similar political systems based on Islamic beliefs, joint destiny and common objectives. The GCC is a regional common market with a defense planning council as well. The immediate objective was to protect them from the threat posed by the Iran-Iraq War and Iranian-inspired activist Islamism (also seen as fundamentalism). In a series of meetings, chiefs of staff and defense ministers of the Gulf States developed plans for mutual defense and launched efforts to form a joint command and a joint defense network. Source: Retrieved from http://www.globalsecurity.org/military/world/gulf/gcc.htm.
} 
us that there is a field that is more suitable for the proper development of Islamic banking in Turkey. Pending Foreign Direct Investment (FDI) made by the GCC shows that the Islamic finance market is largely untapped and promising opportunities to be seized.

On the other hand, even if these institutions seem far from reaching their "golden age”, certain necessary steps should be taken. Indeed, the future prospects for growth and market share would conditionally appear by a better regulatory framework and even by reforming of certain laws and articles that are in conflict with the Sharia. As an example, the opening of a deposit account in accordance with the Sharia is not an easy transaction, because the deposit insurance, imposed by the Turkish regulation (up to 50,000 Turkish Lira), is applied to the participation banks as well, and this is contrary to the principle of sharing profits and losses posed by Islamic finance. These legal and fiscal adjustments are necessary for the proper development of the Islamic finance in Turkey. These adjustments have a cost, but if existing opportunities could be used, these costs can be considered as trivial challenges of the development of the Islamic finance as a real alternative for Turkey. Furthermore, there is a lack of real competition between these four institutions because while two of them are focused on individual customers, the others interested in professional (commercial) customers. This situation creates an oligopoly in both cases. This should alarm the competition authorities to create a competitive environment healthier and more transparent both for customers and investors.

Despite the existence of a real opportunity, the Turkish banking sector itself is quite reluctant vis-à-vis the alternative finance. Indeed, the traditional commercial banks apprehend to a reputational risk and endanger their brand equity. Moreover, as banks, the enterprises could also mask their primary banks' identity for strategic or reputational reasons to obtain the best conditions for money suppliers (Diamond, 1991). Moreover, if the authors consider the most popular commercial bank in Turkey, The İşBankası, which $28.09 \%$ shares are held by the opposition party namely the Republican People (CHP), would offer financial products w the Islamic character, that idea can be considered as utopia. Actually, Turkish conventional institutions have no "Islamic windows".

As stressed by Hassoune (2008a), an analyst at Moody's, the purpose is "to prove that the Islamic finance is neither for certain community, nor tend to attack the dogma of the religious neutrality”. Based on this principle, the Turkish state should make its own sovereign Sukuk as is already made by the UK Treasury, which will attract more investors from the Gulf, and should make itself and especially Istanbul Stock Exchange an important and indispensable actor for Islamic finance. However, the question is that "Does Turkey really want or can offer such a product?" In fact, this action would strengthen the idea that Turkey turns its axis towards the Gulf countries to move away from more and more European-Union and it seems Turkey is not eager to this kind of dealing.

\section{References}

Ahmed, T. E. (2002). Accounting issues for Islamic Banks. In Islamic Finance: Innovation and Growth (p. 76). London. Euromoney Books.

BDDK (BRSA: Banking Regulation and Supervision Agency). (2009, September). Turkish banking sector currency risk assessment reportTürk (BankacılıkSektörüKurRiskiDeğerlendirmeRaporu), Ankara. Retrieved from http://www.bddk.org.tr/WebSitesi/turkce/Raporlar/Kur_Riski_Degerlendirme_Raporlari/7423Kur_Riski_Degerlendirme_Ra poru_Eylul_2009.pdf

BDDK (BRSA: Banking Regulation and Supervision Agency). (2009, December). Overview of the Turkish banking sector (Türk Bankacilik Sektörü Genel Görünümü), Ankara. Retrieved from http://www.bddk.org.tr/WebSitesi/turkce/Raporlar/Diger_Raporlar/7575TBS_Genel_Gorunumu_Aralik2009.pdf 
Bouslama, G. (2008). Islamic finance: A survivor of the tsunami of subprime? (La finance islamique : une rescapée du tsunami des subprimes?) Banque Stratégie, 264, 36-38.

Cihak, M., \& Hesse, H. (2008). Islamic Banks and Financial Stability: An Empirical Analysis. IMF Working Paper. Retrieved from http://www.imf.org/external/pubs/ft/wp/2008/wp0816.pdf

Dabadie, M. (2010). Limits to Islamic finance? (Des Limites à la Finance Islamique?). Revue Banque, 728, 69-71.

Diamond, D. W. (1991). Monitoring and reputation: The choice between bank loans and privately placed debt. Journal of Political Economy, 99, 689-721.

El Qorchi, M. (2005, December). Islamic finance gears up. Finance and Development, 4(4), 2-4. Retrieved from http://www.imf.org/external/pubs/ft/fandd/2005/12/qorchi.htm

Gueranger, F. (2009). Islamic finance: An illustration of ethical finance (Finance Islamique: une illustration de la finance éthique). Dunod (Ed.). Paris.

Hasan, M., \& Dridi, J. (2010). The effects of the global crisis on Islamic and conventional banks: A comparative study. International Monetary Fund Working Paper. Retrieved from http://www.imf.org/external/pubs/ft/wp/2010/wp10201.pdf

Hassan, K. M., \& Lewis, M. K. (2007). Islamic banking: An introduction and overview. Boston: Edward Elgar Publishing.

Hassoune, A. (2008a, July 12). A more welcoming France for Islamic Finance? (Vers une France plus accueillante pour la finance

islamique?) Le Point.fr. Retrieved from

http://www.lepoint.fr/actualites-politique/2008-07-12/vers-une-france-plus-accueillante-pour-la-finance-islamique/917/0/260 022

Hassoune, A. (2008b). Islamic finance in the international financial system and in globalization (La Finance Islamique Dans Le Système Financier International et Dans La Mondialisation). J. P. Laramée (Ed.). Paris.

HSBC. (2010, Novembre 4). Amanah plans to extend operations into Turkey.One page report published.

Islamic Financial Services Board, Islamic Development Bank, and Islamic Research and Training Institute. (2010, April). Islamic finance and global financial stability. Retrieved from http://www.ifsb.org/docs/IFSB-IRTI-IDB2010.pdf

L'Observateur de l’OCDE. (2009). Finance Islamique: un placement d'avenir? 275, Paris.

Moody’s Investors Services. (2008). Islamic finance in France: Strong potential, but key obstacles persist. Retrieved from http://www.institutfrancaisdefinanceislamique.fr/docs/docs/doc_id86.pdf

Ongena, S., \& Şendeniz-Yüncü, I. (2011). Which firms engage small, foreign, or state banks? And who goes Islamic? Evidence from Turkey. Journal of Bank Finance, 35, 3213-3224. doi:10.1016/j.jbankfin.2011.05.001

Subbarao, D. (2009, August 28). Proceedings from Conference on Ethics and the World of Finance Organized by Sri Sathya Sai University. Keynote speech on ethics and the world of finance. Andhra Pradesh. Retrieved from http://www.bis.org/review/r090828c.pdf

Tariqullah, K., \& Habib, A. (2001). Banque Islamique de Recherche de Developpement et Institut Islamique de Recherche et de Formation. Risk Management-Analysis of certain aspects of the Islamic finance industry (La gestion des risques- Analyse de certains aspects liés à l'industrie de la finance islamique). Document Occasionnel, 5, 35-45.

Van Hennie, G., \& Zamir, I. (2008). Risk analysis for Islamic banks. World Bank. Washington, D. C..

Visser, H. (2010). Islamic Finance: Principles and practice (pp. 20-25). Edward Elgar Pub.

Wilson, R. (2011). Islamic finance: Principles and practice. Journal of Islamic Studies, 22, 143-146. 